\title{
Social Work in Kosovo, Development, Challenges and Achievements in Mitigating Negative Social Phenomena
}

\section{Adile Shaqiri}

PhD Cand. Department Social Work, Organization and Management of Social Activities, South-West University "Neofit Rilski”, Bulgaria

Magbule Koci

MA, Pristina, Kosovo

\section{Abstract}

The purpose of this paper is to analyze the importance and impact of Social Work in mitigating negative social phenomena in Kosovo. Kosovo is a country in transition, a country with a high level of education, low economic development, high unemployment rate, high poverty rate, political instability, where we conclude that the increase of negative social phenomena such as: violence in the family, trafficking in human beings, abused children, dysfunctional families, divorce, abuse with psychoactive substances by young people, determine the inevitable need for social work in Kosovo. The thesis of this study is: What is the impact of Social Work in Kosovo in preventing negative phenomena such as domestic violence, violence against women and children? The main focus of this study is the analysis on the necessity and need for strengthening Social Work in Kosovo, the efforts, challenges, confrontations and clashes between time periods and political changes and systems that have already led to a new understanding of Social Work in Kosovo. Within the paper, the main areas taken for study are related to the principles of social work, aspects of social work, the need for social work, professional opportunities in the field of social work and the role of the Social Worker, which are the main axis of this paper. The summary with conclusions and recommendations will be at the end of this.

Keywords: Social work, principles, services, people in need, children.

\section{Introduction}

Social Work in Kosovo, as in other countries, is a practice-based profession and an academic discipline that promotes social change and development, social cohesion and the empowerment of people. The principles of social justice, human rights, collective responsibility and respect for diversity are central issues for social work. Backed by theories of social work, social sciences, humanities and indigenous 
knowledge, Social Work engages professionals and structures to address life challenges and enhance the well-being of individuals, groups and communities.

Social work as an applied science in Kosovo is implemented based on the application of basic sciences to solve social problems. Social work, both theoretically and practically, is applied on the basis of close interdisciplinary links with other scientific fields, such as pedagogy, sociology, psychology, law, ethics, philosophy, etc.

This paper, in itself, focuses on the study and analysis of the necessity and need for the application of Social Work in Kosovo, efforts, challenges, confrontations and clashes between time periods, socio-political changes to the present day.

The main areas of the study in this paper are related to the aspect of academic development of Social Work in the Western Balkans and the countries of the former Yugoslavia, institutional development and professional aspect of Social Work in Kosovo, international and domestic legal framework, role of social workers in treatment and mitigation of negative social phenomena, such as domestic violence, violence against women and children, which are the main axis of this paper.

\section{Methodology}

The methodology of drafting this paper is based on the collection of secondary data from relevant institutions, policy makers, actors and first responders in combating negative social phenomena. The evolution of social work and the treatment of the phenomenon of domestic violence, especially violence against women and children, is described chronologically.

From the statistical data, which derive from the responsible institutions, the social field through different stages of development has been presented and analyzed. A comparison and analysis was also made between the countries of the region, analyzing Kosovo's position in the setting.

Throughout the analysis is described the impact and result that reflects Social Work as a profession, in the prevention, management and protection of victims of domestic violence, violence against women and especially children as the most vital part of our society.

Based on the researched, reviewed and analyzed data, in this paper we raise and promote discussions on the impact of Social Work in mitigating negative social phenomena, as well as in creating a general culture of understanding the importance of further development of Social Work in Kosovo.

1. Theoretical discussions of the impact of Social Work in dealing with phenomena such as domestic violence, violence against women and children

Treatment of negative social phenomena such as domestic violence, violence against women and children have been reviewed and studied by many researchers from a theoretical point of view. 
Theories try to describe, explain and predict social events based on evidence, studies and scientific research. Theoretical approaches of social work with regards to the study of negative phenomena began in the early 20th century by scholars such as; Mary Richmond ${ }^{1}$, Albert Bandura ${ }^{2}$, Erik Erikson ${ }^{3}$, Sigmund Freud ${ }^{4}$, Murray Bowen ${ }^{5}$ etc.

According to Mary Richmond (1917) ${ }^{6}$ the psychosocial framework had its earliest origin in the occurrence of the social issues and environmental conditions as crucial in the situations of individuals. Her observation for each person was unique in the way she/he was treated.

Richmond ${ }^{7}$ was the one who systematically developed the content and methodology of the diagnosis in the period around 1910. Her first principle was that care should be focused on the person within his situation. She also developed and labeled 'Social Diagnosis' during this period. The chart diagram which gained popularity, visually presented the correspondence of the client and the environment. Richmond identified six energy sources that are available to clients and their social workers as sources within the family, within the client community, in civil agencies, in private and public agencies, and so on.

Mary Richmond (1917) with her book "Social Diagnosis", built the foundations for the development of the scientific methodology of professional social work. She analyzed the causes of poverty and social exclusion in the interaction between an individual and his or her environment.

She saw the individual, the family and the group as unrelated to their social environment and social inclusion? ${ }^{8}$.

Systems Theory is the theory that defines humans as products of complex systems and not as individuals acting in isolation. According to this theory, behavior is influenced

\footnotetext{
${ }_{1}^{1}$ Mary Ellen Richmond (1861-1928) - Social Work Pioneer, Administrator, Researcher and Author. She is regarded as the mother of professional social work. She founded social case work, the first method of social work and was herself a Caseworker. For her contributions, Mary Richmond is considered the primary founding profession of the social work profession and the importance of vocational education. ${ }^{2}$ Albert Bandura (1925- 2021) is an influential social cognitive psychologist who is best known for his social learning theory, and the concept of self-efficacy.

${ }^{3}$ Erik Erikson (1902-1994) is best known for his famous theory of psychosocial development and the concept of the identity crisis. His theories marked an important shift in thinking on personality; instead of focusing simply on early childhood events, his psychosocial theory looks at how social influences contribute to our personalities throughout our entire.

4Sigmund Freud was an Austrian neurologist and the founder of psychoanalysis, a clinical method for treating psychopathology through dialogue between a patient and a psychoanalyst.

5Murray Bowen, (1913-1990), Murray Bowen was a 20th century psychiatrist who developed family systems theory, also known as Bowen theory.

${ }^{6}$ Richmond, E.M (1917) Social Diagnosis, New York: Russell Sage Foundation chapter VII

${ }^{7}$ https://socialwelfare.library.vcu.edu/social-work/richmond-mary/

8 Richmond, E.M (1917) Social Diagnosis, New York: Russell Sage Foundation chapter VII page 158 https://socialwelfare.library.vcu.edu/social-work/richmond-mary/
} 
by a series of factors that work together as a system. These factors include family, friends, social settings, religious structure, and economic status. All of these indicators can affect the way individuals act and think, as well as how social problems develop and erupt.

Dr. Murray Bowen (1946), developed family systems theory where he sees the family unit as a complex system, containing its own systems and reacting. The theory of family systems does not contain ideas that were not part of them or of human ${ }^{1}$.

Also, Erik Erikson ${ }^{2}$ in Psychosocial Development Theory believed that personality develops in a series of stages. According to Erikson, among the invisible coordinates of identity is that of the life cycle. By this definition he assumes that until adolescence, the individual does not develop the preconditions in physiological growth, in mental maturity and social responsibility. In order to experience and go through the identity crisis we notice that the management of social problems such as domestic violence, violence against women and children is a consequence of past experiences. Erikson developed a theory with eight psychosocial stages of development ${ }^{3}$.

Sigmund Freud and the Psychodynamic Theory is based on the idea that humans are biologically driven to seek pleasure. The theory explains that human's act based on processes that have developed outside of consciousness originating from childhood experiences. This stimulus affects daily behavior, leading to actions like aggression, sex, and self-defense.

In social work, psychodynamic theory has helped social work professionals in explaining the internal processes of individuals. Based on this theory Social workers can examine early childhood experiences as they may have an impact on influencing clients' behavior. It could be noticed how domestic violence or violence against women and children is like a model carried from their traumatic childhood.

Social Learning Theory is also known as social cognitive theory. Psychologist Albert Bandura claims that learning happens by observing others and modeling their behavior ${ }^{4}$. According to Bandura many theories have been proposed over the years to explain human behavior. Recently, some theorists thought that motivating forces in the form of needs, incitement and impulses, which often operate below the level of consciousness, were the main determinants in human behavior. Bandura, in his book, Social Learning Theory ${ }^{5}$ states that the value of a theory is ultimately judged by the power of the processes it generates and influences social and psychological change.

\footnotetext{
1 Bowen, M., M.D. (1978) Family Therapy in Clinical Practice, Rowman \& Littlefield publishers, INC ${ }^{2}$ Erikson, H. E. (1968) Identity Youth and Crisis, London: Norton \& Company, INC

${ }^{3}$ According to development theory's psychosocial of E. Erickson, the eight stages of development that people go through in life are: 1.Belief versus disbelief, 2.Autonomy versus shame and doubt, 3.Initiative versus guilt, 4.Industry versus inferiority, 5. Identity versus confusion, 6. Intimacy versus isolation, 6. Generativity versus stagnation, 8 . Integrity versus despair.

${ }^{4}$ Bandura, A. (1977) Social Learning Theory, New Jersey: Stanford University, Englewood Cliffs, p.4

${ }^{5}$ Same source p.2
} 
2. History of the development of Social Work in the countries of the former Yugoslavia

If we refer to the historical context of the development of Social Work in the countries of the former Yugoslavia, where Kosovo was part of it until the dissolution of the Yugoslav Federation, the first Study Centre for Social Work was established at the University of Zagreb (Croatia) in 1952, as the first social work program in former socialist countries ${ }^{1}$. Social work education was first developed after World War II, and social work was a welfare state mechanism. In the early 1970s, this connection was challenged and the focus of social work education shifted to a more scientific basis. From that period until today, the University of Zagreb ${ }^{2}$ has developed and offered social work and social policy programs in graduate and postgraduate studies.

In Slovenia, the first School for Social Workers ${ }^{3}$ was opened in $1955^{4}$. In the 1970s, the school became part of the University of Ljubljana as a college. After a long struggle, in 1992 Social Work was then consolidated into a four-year program and developed postgraduate specialization programs. Since its establishment ${ }^{5}$, this institution has been a pillar of the development of Slovenian social work and the field of social protection, developing special areas such as: work with the elderly, women, young people, people with mental health problems, physical disabilities, ethnic minorities etc.

The beginnings of the development of Social Work in Serbia, namely, university education for social policies and social work began in the academic year 1973/74 at the Faculty of Political Science (FPS) ${ }^{6}$ in Belgrade. FPS was the first higher education institution for the education of social workers and to date, FPS offers complex interdisciplinary study programs in the field of Social Work and Social Policy. Regarding Macedonia, now Northern Macedonia, the Institute of Social Work and Social Policy at the Faculty of Philosophy, within St. Cyril and Methodius University in Skopje was first established in 1957 as a high school which marked the beginning of the education of social workers. In 1960, the high school was transformed into a College of Social Workers, with a two-year program. Meanwhile, in 1984, the College of Social Workers joined the Faculty of Philosophy in Skopje. The University of Sarajevo ${ }^{7}$, based on the research we conducted in the interest of this paper, found that this public university located in Sarajevo (Bosnia and Herzegovina) is one of the

\footnotetext{
${ }^{1}$ Bundschuh, S., José, M., Càndid, F., Bartrolí, P. \& Žganec, N. (2021) Ambivalences of Inclusion in Society and Social Work Editors Research-Based Re-sections in Four European Countries, Springer 2021 ${ }^{2}$ https://www.eassw.org/schools/study-center-of-social-work-faculty-of-law-university-of-zagreb/ 3https://www.fsd.uni-lj.si/fakulteta/fakulteta/poslanstvo/)

4https://www.revija-socialnodelo.si/

5https://www.fsd.uni-lj.si/raziskovalno_in_razvojno_delo/

${ }^{6}$ https://www.fpn.bg.ac.rs/studije-socijalne-politike-i-socijalnog-rada

7https://fpn.unsa.ba/b/historijat-fakulteta/
} 
oldest Universities as well as the oldest institution of tertiary education in the former Yugoslavia, tracing its initial origins in 1537 as an Islamic ${ }^{1}$ Madrasa $^{2}$. Within the Faculty of Political Sciences is also the Department of Social Work as one of the specialties from more than 150 courses of theoretical disciplines to those specialapplied ones.

\section{History of Social Work development in Kosovo}

In the period before the 90s, Kosovo had its own system of social protection under the general umbrella of the legislation of the former Yugoslavia. This included disability pension insurance, unemployment benefits, child benefits (known as child allowances), low-income workers, and social assistance for low-income families. Within the mechanisms of that period, qualified staff in the social sciences was engaged, but there were very few qualified social workers. Professionals at the time came mainly from schools in other parts of the former Yugoslavia. Seen from this perspective, Social Work as a profession has been practiced by Educators, Sociologists, Philosophers, Lawyers, etc., who have been engaged within social protection institutions such as Centres for Social Work in some of the country's municipalities, pension offices, Institute of Social Policy. After the break-up of the former Yugoslavia and the end of war and conflicts in Kosovo, the development of normal life returns after 1999, when the United Nations Security Council issued Resolution 1244, which established Kosovo under the United Nations Interim Administration (UNMIK ${ }^{3}$ ). A joint and interim administrative structure was established in February 20004, where the first steps of the formation of Institutions and self-government began. Compared to the academic developments of the countries of the former Yugoslavia, in Kosovo the first institution of higher education was the Higher Pedagogical School in Pristina (1958). After approximately 55 years, in 2012, within the University of Pristina, the Department of Social Work ${ }^{5}$ was established. The first generation of social workers after the establishment of the Department of Social Work graduated in 2016. To date about 40 (forty) students graduate each academic year.

\section{Social Work now}

In addition to all the challenges that characterize a country in the post-war periods, Kosovo also faced many economic, political, social challenges and problems.

The paper reflects the empirical evidence related to the values, ethics and daily practice of social workers and other social service providers between the changes and crises that Kosovo has experienced and the transition in the last two decades,

\footnotetext{
${ }^{1}$ https://fpn.unsa.ba/b/historijat-fakulteta/

2 http://upis.unsa.ba/en/ustanove/faculty-of-political-sciences/

3 World Bank and DFID (2006) Social Protection Position in Kosovo, p.10:Pristina

${ }^{4}$ Same source;

5https://filozofiku.uni-pr.edu
} 
such as the erosion of the welfare state, the occurrence and the development of negative social phenomena, demographic movements within the country, emigration, etc. that have generated marginalized groups of different social layer.

${ }^{1}$ In this perspective, Kosovo was characterized by a prolonged transition in many spheres of life. Certainly with the help of the international factor in Kosovo, numerous international organizations installed in Kosovo, the country's institutions, managed to create the preconditions for the functioning of the country, the independence of the state of Kosovo, strengthening and gradual consolidation of institutions, for economic development, poverty alleviation, job creation, development of the nongovernmental sector, development of the private sector, alleviation of other social problems. In parallel with these developments the above-mentioned phenomena appeared and are present, including domestic violence and violence against women and children that are the focus of this paper.

5. Impact of Social Work on protection victims of domestic violence, Women and children

In the steps of state formation, development and consolidation of Institutions in Kosovo, the social welfare developed through Social Work also takes place. Although the history of Social Work in our society is evident that in 1964 with the establishment of the first Centres for Social Work, in some municipalities of the country, begins and develops the application of social work methods and other methods on the principles of humanities, where a legal infrastructure of that time was created and now continues, harmonized with EU laws. In this context, social policies and support programs have been developed for the protection of categories for persons in need of social services.

The impact of Social Work on mitigating negative social phenomena such as child abandonment, child abuse and neglect, violence against women and children, violence against the elderly, people with disabilities are just some of the categories that social work and professionals within this profession assist in the identification, protection, rescue, support, empowerment and reintegration of ex-victims and survivors. According to the World Health Organization, 1 in 3 women experience violence in their lifetime and that most of these cases are cases that derive from domestic violence 2 . According to the Evaluation Report of the Kosovo Program Against Domestic Violence ${ }^{3}$, on average about 1000 victims per year are assisted by responsible institutions where 80 percent of them are women and children. Data

\footnotetext{
${ }^{1}$ Milligan, I. (2015) Strengthening family based care, strengthening social work A situation analysis of foster care in Kosovo : Prishtine, UNICEF, 2016 2World Health Organization "Violence Against Women" 2017 https://www.who.int/news-room/factsheets/detail/violence-against-women 3 Kosovo Anti-Domestic Violence Program Evaluation Report https://abgj.rksgov.net/assets/cms/uploads/files/Publikimet20ABGJ/Raporti_shqip.pdf
} 
published by the OSCE ${ }^{1}$ show that every second in ten men has witnessed physical violence against their mothers. Even in Kosovo, the phenomenon of domestic violence has deep roots, motivated by patriarchy, the socio-economic situation of women compared to men and the harmful stereotypes that society has created. External factors such as poverty, unemployment, loss of jobs work, unstable political situation, and internal factors such as inequality, isolation, social distance, and disordered relations of spouses, divorce, stigma, drug and alcohol abuse, economic dependence have also contributed to and continue to increase the incidence of violence in the family, where the above factors are evaluated as a determining factor in the growth of this phenomenon.

Based on the analysis above, the need for social work professionals is increasing day by day. The need for social work professionals stems from the fact that factors such as poverty, inequality and social exclusion are often used to refer to the same phenomenon. But while poverty and inequality are consequences, social exclusion is both a consequence and a process ${ }^{2}$, and inevitably a deterrent to domestic violence. In cases where we have social exclusion and intersection with poverty caused by a group of multiple and interrelated disadvantages, which then lead to poverty, extreme poverty, unemployment also generate negative phenomena such as domestic violence with special emphasis on women and children as sensitive and vulnerable categories.

Data on identified cases of domestic violence during the years 2015-2020, presented below in an inalienable and necessary way highlight the need for help and support that social work professionals can provide.

\section{Cases of domestic violence during the period 2015-2020}

1.5

1

0.5

0

Chart 1. (Source: Kosovo Police)

The graph reflects the data for the period 2015-2020 at the national level. The data presented are data on cases identified by the Kosovo Police and handled by the Social Services in Kosovo. Regarding the data which were presented during 2020 by the

\footnotetext{
1 Same source

2 Measuring, Monitoring and Reporting Oriented Policies Results Social Inclusion Policy Paper 20162020. February 2016. Republic of Albania Ministry of Social Welfare and Youth
} 
Ministry of Internal Affairs, respectively the Kosovo Police ${ }^{1}$ during 2020, $2069^{2}$ cases were reported, as well as during 2020,14 murders were reported with 23 victims of domestic violence, 6 out of 23 victims were young women and girls. Domestic violence even during the first six months of 2021 continues with high figures were 1,063 cases are in the records of the Kosovo Police. 3 women were killed during the first half of 2021 and the recent murder of a young 18-year-old girl recently, according to suspicions, by her fiancé, shocked Kosovo again. An 18-year-old girl was left without signs of life in front of the hospital of her hometown by two people who had left without a trace ${ }^{3}$. The public opinion and the Civil Society Organizations in Kosovo, shocked and indignant on the occasion, showed public reaction by organizing protests in the city of the macabre event as well as in several other cities of the country.

6. Legal, institutional and professional framework for protection from domestic violence in Kosovo and the role of social workers in these processes

In the case of Kosovo, when it comes to domestic violence, violence against women and children, the mere existence of a national legal framework or international conventions applicable in the country is not enough to improve the situation and reduce domestic violence and violence against women, and children. The application of protection measures, expressed in the law, becomes almost impossible without effective inter-institutional coordination that enables the planning of adequate resources, the provision of quality services, the establishment of necessary criteria and standards and the monitoring of their implementation.

In the Republic of Kosovo, respectively in its Constitution ${ }^{4}$, in Article $22^{5}$ (Direct Implementation of International Agreements and Instruments) are automatically incorporated international agreements and instruments, which guarantee human

\footnotetext{
1 https://md.rks-gov.net/

2 Kosovo Police, Annual Report 2020

3 https://kallxo.com/lajm/18-vjecarja-qe-u-dergua-pa-shenja-jete-ne-spitalin-e-ferizajt-ka-shenjadhune/

${ }^{4}$ Constitution of the Republic of Kosovo, 2008 Assembly of the Republic of Kosovo, Kosovo

5The following international agreements and instruments, which guarantee human rights and freedoms and are guaranteed by this Constitution, are directly implemented in the Republic of Kosovo: (1) Universal Declaration of Human Rights;

(2) European Convention for the Protection of Human Rights and Fundamental Freedoms and its Protocols;

(3) International Covenant on Civil and Political Rights and its Protocols;

(4) Council of Europe Framework Convention for the Protection of National Minorities;

(5) Convention on the Elimination of All Forms of Racial Discrimination;

(6) Convention on the Elimination of All Forms of Discrimination against Women;

(7) Convention on the Rights of the Child;

(8) Convention against Torture and Other Cruel, Inhuman or Degrading Treatment or Punishment, Inhuman and Humiliating.

(9) Council of Europe Convention on Preventing and Combating Violence against Women and Domestic Violence-Istanbul Convention2011
} 
rights and freedoms and are guaranteed by this Constitution, and are implemented directly in the Republic of Kosovo and have priority, in case of conflict, over the provisions of laws and other acts of public institutions. The Law on Child Protection in Kosovo also complements the legal framework regarding child protection. While the Law on Protection from Domestic Violence ${ }^{1}$ in the first article defines the purpose for the prevention of domestic violence, in all its forms, with measures that are legally appropriate for family members who are victims of domestic violence, by paying special attention to children, the elderly and people with disabilities. All these legal acts would not be implementable without harmonization with the Law on Social and Family Services.

Through the institutional framework or Institutional Mechanisms, the State has an obligation to protect the rights of individuals ${ }^{2}$. Domestic violence is recognized as a violation of these rights. The state therefore has an obligation to assist victims of domestic violence, to ensure that they are treated with dignity, care and respect by the institutions and individuals representing the state.

Identification and referral as well as protection are a continuing obligation ${ }^{3}$ of social service providers. If there is any risk to the victim or witnesses all measures should be taken to ensure the safety of the individual regardless of the stages of the proceedings. Referring to the document of standard action procedures for protection from domestic violence in Kosovo, Centre for Social Work (SOP, 2013) for all referred or identified victims provides social and family services based on the assessment of the needs of the victim and has the obligation to coordinate social services for the victim until his / her reintegration into society. Victims are also advised on the availability of services by institutions and NGOs that provide protection and rehabilitation programs for victims of domestic violence. The Custodian Body which operates within the Centre for Social Work is obliged to respond in a timely manner to any request for professional opinion submitted by law enforcement agencies such as the court, prosecution, police (SOP, 2013). Social service professionals after assessing the needs of the victim provide social services for the victim such as psychosocial counselling, remediation of domestic violence, guardianship, short-term housing only when deemed necessary by the actors that it is necessary for the victim's safety, assistance and empowerment of a victim / survivor until his / her reintegration.

\section{Conclusion}

In Kosovo, social services provided through social work methods for individuals, families and groups and communities at risk are the competence of various institutions and organizations at the central and municipal levels and are mandated

\footnotetext{
${ }^{1}$ Law no. 03 / L-182 on Protection From Domestic Violence

2Standard Operation Procedures (SOPs) for Protection from Domestic Violence in Kosovo, Pristina: 2013 , Agency for Gender Equality, Office of the Prime Minister

${ }^{3}$ Same source;
} 
by law to provide social services or implement programs and activities that intend to improve the approach to these services. Social services are designed to serve, in addition to other sensitive categories, victims of domestic violence with focus on women and child victims.

Violence against women is the most common form of gender-based violence in Kosovo and broader. In "Declaration on the elimination of violence against women", of the General Assembly of United Nations) (UN) recognizes that violence against women is an expression of the historically unequal power relations between men and women, which has led to domination and discrimination against women by men and to the impediment to the full advancement of women, and that violence against women is one of the main social mechanisms by which women are forced to hold submissive positions as compared with men. Social norms and attitudes regarding the role that women should play in society and the widespread acceptance of gender inequality set the context for violence against women. They instil even more inequality in a society where men dominate at home, at work and in the public sphere. Recognition, acceptance and prioritization of cases of domestic violence and violence against women, undoubtedly requires a much greater awareness of women, men, girls and boys in Kosovo, as well as the entire central and local responsible institutions, about the risks, the consequences and costs brought to the country by the lack of such a well-coordinated response. Kosovo has a history of social protection of its citizens, among others, through social work. It should be noted that social services are at an important stage of development, where the emphasis is on meeting the current needs of vulnerable groups in society, improving the quality of services and decentralizing the financial and administrative management of social services and handing over to municipal level. This paper itself has also analysed theoretical approaches regarding the impact of social work on vulnerable categories such as victims of domestic violence, women and children. An analysis has also been made regarding the historical developments of Social Work in the countries of the former Yugoslavia and Kosovo in the past and now. A detailed review also describes the legal framework and its implementation, the institutional and professional framework for protection from domestic violence in Kosovo, and the role of social workers in these processes.

\section{Recommendations}

Social services offered through the methods of Social Work in Kosovo are focused on all groups in society, with an emphasis on women, girls, children, victims of various forms of domestic violence, victims with disabilities, victims from ethnic minorities, LBTI +, the elderly, single mothers, girls, mothers, migrants, asylum seekers, etc.

Reducing and mitigating judgmental attitudes and behaviours that support violence in the family, through information, education, and the ongoing awareness-raising of professionals, the community, and the whole society.

In the Kosovar context, social work at the academic level, including the first and 
second cycle of studies, should develop and advance numerous programs and profiles of social work. .

Consider the recruitment and selection of social workers specialized in dealing with cases of gender-based violence, domestic violence and violence against women and children.

The use of a "victim-centred approach" is recommended that social work professionals should always strive to prioritize the needs and preferences of victims of violence.

Institutions and social work professionals should minimize harm and increase the safety of persons who have experienced violence, by considering with priority the sensitivity and confidentiality.

Ensuring comprehensive and efficient institutional mechanisms for rapid response to cases of domestic violence, as well as responsible inter-institutional cooperation, between the participating parties, at central and local level, for the protection and management of these cases.

Improving the legal infrastructure and increasing the efficiency of handling cases of domestic violence, with a focus on the needs of the victim, as well as adequate punishment of the perpetrator.

Enabling, throughout the territory of Kosovo, access to new and existing social services, efficient and sustainable for the rehabilitation and long-term reintegration of victims of domestic violence

\section{References}

[1] Bandura, A. (1977) Social Learning Theory, New Jersey: Stanford University, Englewood Cliffs, p.4

[2] Bowen, M., M.D. (1978) Family Therapy in Clinical Practice, Rowman \& Littlefield publishers, INC

[3] Bundschuh, S., José, M., Càndid, F., Bartrolí, P. \& Žganec, N. (2021) Ambivalences of Inclusion in Society and Social Work Editors ResearchBased Re-sections in Four European Countries, Springer 2021

[4] Constitution of the Republic of Kosovo, 2008 Assembly of the Republic of Kosovo, Law no. 03 / L-182 on Protection From Domestic Violence

[5] Erikson, H. E. (1968) Identity Youth and Crisis,London: Norton \& Company, Inc. London

[6] https://abgj.rksgov.net/assets/cms/uploads/files/Publikimet20ABGJ/Rapo rti_shqip.pdf

[7] https://filozofiku.uni-pr.edu/page.aspx?id=1,65

[8] https://fpn.unsa.ba/b/historijat-fakulteta/

[9] https://kallxo.com/lajm/18-vjecarja-qe-u-dergua-pa-shenja-jete-nespitalin-e-ferizajt-ka-shenja-dhune/ 
[10] https://md.rks-gov.net/

[11] https://socialwelfare.library.vcu.edu/social-work/richmond-mary/

[12] https://www.aph.gov.au/binaries/library/pubs/rp/1995-96/96rp14.pdf

[13] https://www.eassw.org/schools/study-center-of-social-work-faculty-oflaw-university-of-zagreb/

[14] https://www.fpn.bg.ac.rs/studije-socijalne-politike-i-socijalnog-rada

[15] https://www.fsd.uni-lj.si/fakulteta/fakulteta/poslanstvo/

[16] https://www.fsd.uni-lj.si/raziskovalno_in_razvojno_delo/

[17] https://www.revija-socialnodelo.si/

[18] https://www.uni-pr.edu/page.aspx?id=1,8

[19] https://www.who.int/news-room/factsheets/detail/violence-againstwomen

[20] Kosovo Anti-Domestic Violence Program Evaluation Report

[21] Kosovo Police, Annual Report 2020

[22] Measuring, Monitoring and Reporting Oriented Policies Results Social Inclusion Policy Paper 2016-2020. February 2016. Republic of Albania Ministry of Social Welfare and Youth

[23] Milligan, I. (2015) Strengthening family based care, strengthening social work A situation analysis of foster care in Kosovo : Prishtine, UNICEF, 2016

[24] OSCE/UNFPA - Men's Perspective on Gender Equality in Kosovo https://www.osce.org/mission-in-kosovo/382507

[25] Richmond, E.M (1917) Social Diagnosis, New York: Russell Sage Foundation chapter VII page 158 Family

[26] Standard Operation Procedures (SOPs) for Protection from Domestic Violence in Kosovo, Prishtina 2013 Agency for Gender Equality, Office of the Prime Minister

[27] Standard Operation Procedures (SOPs) for Protection from Domestic Violence in Kosovo, Pristina: 2013 , Agency for Gender Equality, Office of the Prime Minister

[28] The Collapse of Yugoslavia (1995) Background and Summary, Commonwealth of Australia: Department of the Parliamentary Library.

[29] World Bank and DFID (2006) Social Protection Position in Kosovo, p.10: Pristina

[30] World Health Organization "Violence Against Women" 2017 